\title{
Whither Corporate Russia?
}

\begin{abstract}
Using firm-level information obtained from RTS stock exchange over the 1998-2006 period, we estimate growth performance of the Russian corporate sector. We find consistently improving growth, and note that higher growth performance is correlated with a higher state partial reacquisition and corporate governance presence in corporations. We argue the latter served to not only safeguard against misappropriation of firm assets and government subsidies, but also to guard against propensity of managers to opt for shorter than optimal investment time horizon. Thus the state corporate governance strategy may serve as a second best policy to a more developed property rights system.
\end{abstract}

JEL Codes: P26, P34, G32

Keywords: State-private co-partnership, hold-up costs, Russia 


\section{Introduction}

In this paper we use firm-level financial data of companies listed on the Russian Trading System stock exchange (or RTS) to estimate corporate growth performance starting from the beginning of 1998 through to the end of 2006 . We are particularly interested in identifying possible causes behind the remarkable turn-around in Russian corporate growth for most of this period, especially when contrasted with the previous decade's severe negative growth (-14.5 percent in 1992) ${ }^{1}$. Table 2 (see further text) applies a standard measure of Tobin's Q to compare average corporate growth performance over three sub-periods. The measure essentially captures the ratio between a company's market value divided by the replacement costs of its assets, typically represented by the book value of its assets. As we see from 1998-1999 Tobin's Q averaged just 0.357 , in the period $2000-2002$ it averaged 0.432 and in the period 2003-2006 it averaged a remarkable 0.844. Our data set only covers a few years of the late Yeltsin regime, but for most of the nineties decade corporations experienced severe disinvestment and suffered large negative growth rates. This phenomenon is generally attributed to increasing proclivity, over the Yeltsin's regime's tenure of office, of inside investors, who in many cases were former stateenterprise managers and local government bureaucrats, to engage in widespread asset substitution, which included the liquidation of many former state-firm assets, which were often transferred into illicit overseas accounts (Intriligator, 1998).

The failure of the privatization initiative of the Yeltsin regime, and the ensuing Russian economic collapse that came in its wake, is widely attributed to the regime's failure to initiate an effective property rights structure, which is assumed vital to

\footnotetext{
1 See Conditions in Russia at the Outset of the Yeltsin and Clinton Administrations, http://www.fas.org/news/russia/2000/russia/part02.htm
} 
encourage efficient firm level investment (Stiglitz, 2002). Moreover, the descent of the economy toward regionalization served only to undermine the ability of the central government to even enforce what regulations it had against misappropriation by many managers, often in alliance with regional officials of former state enterprises (Coffee, 1999; Fox and Heller, 2000).

The remarkable turn-around in corporate growth, which began early under the Putin regime, has been largely attributed to significant subsidies, stemming from Russia's substantial natural resource export earnings, received by many firms located in targeted industries. Undoubtedly, greatly enhanced subsidies derived from natural resource rents played an important part in Russian corporate revival, but it can never be the whole story. Recall, for example, that the Yeltsin regime had also carried out an investment subsidy allocation scheme to favoured firms, but as we know, severe negative corporate growth persisted, even for firms most favoured through generous subsidies. The latter most likely diverted from legitimate investment projects in order to personally enrich in situ managers and local bureaucrats (Rock and Solodkov, 2001).

Thus, an important factor for the turn-around in corporate growth must also lie somewhere else. The new regime had earlier introduced a wide range of nominally strong corporate governance reforms, such as increasing transparency and disclosure (Yakovlev and Osteuropa, 2003; Lazareva et al., 2007). For example, Russian firms acquired both ownership and corporate governance qualities similar to that of a Western-style firm, and a firm's shareholders elect Western-style board of directors for each firm, the latter enjoying a wide latitude in determining corporate strategy (Porshakov et al., 2006). Even if we were to accept that the above mix of policy initiatives had played a role in guaranteeing outside investors against the most 
egregious asset-stripping behaviour by inside investors that was so prevalent in the earlier decade, such policies would not have prevented the propensity of local managers and bureaucrats toward adopting a sub-optimal investment horizon. This is due to the continuing perceived lack of confidence in the legal property rights protection when it comes to the fruits of longer-term large lumpy investments (Woodruff, 2005; Greenspan 2008), especially when these investments projects receive generous state subsidies in the initial period.

Based on the above, we argue that the Putin regime's reversal of its predecessor's strategy of disengagement from firm-level decision-making is the most significant factor that enhanced corporate sector growth. For example, the state became a substantial co-owner in just about all of the major corporations, and crucially exercised its option to have a significant presence within the shareholder bodies, particularly with corporations receiving substantial investment subsidies. The importance of this kind of state-private co-partnership system (SPCS) can be recognised as a monitoring mechanism necessary in order to protect firm-specific investment subsidies from expropriation by investor insiders, which was a widespread practice during the 1990s (Goldman, 2003; Gregory and Schrettl, 2004; Bahry, 2005; Dininio and Orttung, 2005; Ivanenko, 2005; Tompson, 2005). In other words, we argue that SPCS plays a subtle role in preventing inside investors from sub-optimally terminating longer-term investment projects, especially state-subsidized projects. Thus SPCS may serve as a second-best substitute for a more effective legal system, which would act to guarantee any expected income flows from any large lump-sum initial outlays. Asset-stripping behaviour by insiders is of course an extreme example of the above, but one that expropriates the investments outlays of private investors as well. 
Under SPCS, firms could continue to be owned, often predominately so, by outside shareholders. Indeed, company shares freely trade through organized exchanges. This has the advantage that corporations would be able to raise capital through new share issues. However, under SPCS, this would be more constrained to adhere to the preconditions of any subsidized state loans.

Of course the SPCS system would not impinge on the ability of any Russian corporation as before under the more laissez-faire Yeltsin policy of being able to determine their optimum level of output according to relatively freely determined market prices. However, it can be argued that the targeted subsidized investment system of the central government could seriously distort the optimal output mix of the economy. However, any state directed investment strategy is more credible the more certain it knows the relative productivity and technology of the overall corporate sector. It can be argued this would be all the more likely in the case of Russia as it can imitate more advanced neighbours having advanced market economies. Consequently, Russia could more easily estimate the level of its initial fixed investment, which together with an estimate of the productive technologies of the various investment projects, can allow the state to estimate each type of firm's optimal investment duration and thereby the determination of the optimal allocation of investment subsidies. Thus, though the modern Russian state differs fundamentally from its tsarist ancestor, its investment strategy can be defined as Gerschenkron-esque.

The remainder of this paper is structured as follows. Section 2 examines the adverse effects of the privatisation initiative, which can in large part be attributed to a poorly-developed property rights system. Section 3 provides data description and summary statistics, while Section 4 interprets empirical results. Section 5 offers conclusions and ideas for further research. 


\section{A faltering step toward privatization}

The catastrophic decline of Russian industrial output from the early 1990s to the turn of the new millennium is largely attributable to the Yeltsin regime's badly executed strategy to free the nation's industrial enterprises from its traditionally state-centred planning system, which, despite Gorbachev's previously efforts, still mandated production quotas for all the nation's major enterprises. The early goal was to evolve to a freer market-price allocation system, whereby each enterprise's investment decisions would be more efficient. An important aspect of this strategy was to transfer state enterprise ownership into private hands. The headlong drive toward privatization was so rapid that by 1996, it was estimated that approximately 77.2 percent of large and medium size firms were acquired by private owners, and this figure corresponded to 88.3 percent of Russia's industrial output (Debardeleben, 1999).

The distributional story behind Russia's rapid privatization of most of the former state enterprises is the more interesting aspect for this paper. In particular, we are interested how, at the beginning of our sample period, ownership of the major Russian industries ended up in the hands of a small elite oligarchy, despite well intentioned early schemes to allocate share ownership among a broad spectrum of the Russian public. To this end, during the early 1990s, ownership shares were allocated to the employees of many small and medium sized firms. Yet another scheme allocated vouchers to millions of ordinary Russian citizens, which were to be made convertible into ownership shares of various state enterprises at a later date. Nevertheless, very early in the state's privatization drive, in situ managers and local bureaucrats attained sizable ownership stakes of many newly privatized firms at substantially subsidised rates. Shleifer and Vishny attribute the success of the manager's ownership grab to the 
fact that top state enterprise managers were adept at bribing influential politicians, a practice they honed during the former Soviet system (Shleifer and Vishny, 1998).

Despite the fact that former managers and local bureaucrats had gained de facto ownership over large sections of Russian industry, their ownership remained insecure, perhaps not least because of the illegality in the way that they had acquired it (Intriligator, 1994). For example, Hoffman (2002) describes the decade of the 1990s as one plagued by insider dealings, theft and extensive hidden money flows. Other authors have described the widespread practice during the 1990s of Russian company managers engaging in substantial asset-stripping of company resources (Rapaczynski, 1996; Alexeev, 1999; Black et al., 2000; Sonin, 2000; Kuznetsov and Muravyev, 2001). Furthermore, other authors have described how widespread managerial misappropriation of assets was made possible through the connivances of regional bureaucrats who had become increasingly powerful during this period (Robinson, 2002). For example, regional officials exploited the existing differences in public spending initiatives and even competed to assign regional 'property rights' over many enterprises, allowing them to win control over many firms through locally run shares auctions, which were rigged to exclude outside bidders (Guriev and Rachinsky, 2005).

As many authors have argued, the severe asset-stripping behaviour of the rising oligarchs was a predictable consequence due to the absence in Russia of an adequate property rights system (Stiglitz, 2002). An efficient property rights system would ensure that each asset owner enjoys the correct bundle of rights to effect that all assets are allocated to their highest valued uses (Coase, 1960; Demsetz, 1967; Alchian, 1977). This of course includes the right to be freely traded, and Alchian points out that this definition is sufficient to prevent utilization of any assets such that may generate any form of externality (Alchian, 1977; Alchian and Allen, 1977). 
The above abstract definition has spawned a wide range of literature specifying conditions when property rights systems might fail. One well known application relates to moral hazard and adverse selection problems, which can arise in markets of incomplete information. In this tradition, the corporate finance literature has identified costs associated with a wide variety of management monitoring failures afflicting the modern Western corporation (Harris and Raviv, 1991). However, transaction costs arising from moral hazard and adverse selection problems are generated each period under some ongoing contractual relationship between managers, shareholders and bondholders. As this type of problem creates flow costs, it fails to capture the magnitude of the moral turpitude of the rising Russian oligarchy of the period to grasp the lion's share of Russia's vast corporate asset base.

Perhaps of more applicability to the Russian situation of the period is the set of problems generated under an inefficient property system that gives rise to hold-up costs. High hold-up costs can arise when one side of an agreement can act to prevent the application of a jointly owned asset in such a way as to reduce its value. Klein et al. (1978) and Williamson (1979) identify that hold-up costs can arise under an incomplete contract requiring a high degree of asset specificity. But we can apply the theory to better understand the behaviour of the emerging Russian oligarchs also. Through their widespread misappropriation of firms' assets, managers succeeded in undermining the value of the company shares and vouchers held by millions of workers and the larger Russian citizenry. In addition, Russian citizens were also encouraged to sell their vouchers more cheaply due to economic hardship, which of course was a direct consequence of the severe disinvestment due to extensive assetstripping behaviour by the very managers buying vouchers. Thus vouchers worth 10,000 roubles eventually traded at 60 percent discount as ordinarily investors became 
dubious in regard to the size of any income derived from voucher ownership (Broadman, 1999).

Corresponding to the level of disinvestment dynamic state finances also deteriorated and by the mid 1990s the central government was forced to adopt drastic measure to find income. One such measure was the 1995 'loans for shares' scheme, whereby banks and similar institutions advanced loans to the government, with many of the nation's largest state-enterprise shares acting as collateral. During the period, many large private banks were actively engaged in diverting resources to favoured industries and individuals, eschewing to simply play the traditional financial intermediary role. It is claimed that the participating private banks were controlled by friends of many prominent politicians of the regime (Thomson, 2002; Spicer and Pyle, 2003). As the government proved incapable of reversing its fortunes in regard to falling revenue, it inevitably defaulted on its bank debt. Consequently the state enterprise shares held by the banks as collateral were sold by auction. As the number of accepted participating bidders in the share auctions was extremely restricted to a class of investors all of whom were on familiar terms, unsurprisingly shares traded at artificially low prices (Dyck, 2002; Puffer and McCarthy, 2003).

With the completion of the auction, and their recent acquisition of the vouchers, the managerial class in alliance with elements of the old state bureaucracy now held title to the most desirable and important enterprises of the country. The 'new breed' of business leaders - new elites, became known as the Russian oligarchs (Braguinsky and Yavlinsky, 2000; Shleifer and Treisman, 2005). However, the legal title of the oligarchs over their former state enterprises remained politically insecure (Clarke and Kabalina, 1995; Nellis, 1999; Stiglitz, 2002; Hoff and Stiglitz, 2004). Thus, it of little surprise, that once capital funds became freely exportable through a complicit private 
banking system, the period saw capital flight out of Russia (Wintrobe, 1998; Ross, 2004).

Thus, as already stated above, the Putin regime formed SPCS in order to avoid the "grabification" processes of the 1990s. By forming a co-ownership system with private investors, the federal government may significantly reduce high hold-up costs, as the new SPCS can act as an effective monitoring mechanism to more assure private investors of their expected return. The co-partnership system, which is currently evolving in Russia, lies somewhere between complete state ownership of corporations as in the old Soviet Union, and the disastrous 'laissez-faire' system, which existed during the Yeltsin era, but operated with incomplete claims over assets. Our hypothesis suggests that firms are likely to exhibit superior performance and growth prospects if they have adopted the new state-private co-partnership system, which can assure long-term expected return on investment.

\section{Methodology and Data}

\subsection{Methodology and description of variables}

The aim of this research is to measure any effect of the state-private co-partnership system introduced by the early Putin regime. We look at firm performance as well as possible growth prospects. Our regression takes the following form, where X1 denotes ownership type, while $\mathrm{X} 2$ represent a number of control variables:

$$
\mathrm{Y}_{\mathrm{it}}=\beta_{0}+\beta_{1} \mathrm{X}_{1 \mathrm{it}}+\beta^{\prime}{ }_{2} \mathrm{X}_{2 \mathrm{it}}+\varepsilon_{\mathrm{it}}
$$

Our analysis employs a random effects panel regression on the RTS annual firm-level data, obtained from company financial statements available on SKRIN database for 
the period of $1998-2006 .^{2}$ The dataset is comprised of 329 companies, which is a complete sample of firms listed on the RTS stock exchange. However, due to the absence of information, the final sample was reduced to 253 , resulting in 1,737 observations. $^{3}$

The dependent variable in this study is Tobin's Q, which is a measure of company's corporate growth performance. We specifically chose Tobin's Q over return variable due to potential problem associated with the latter measure, which reflects short-term opportunism instead of long-term performance. In other words, we believe that shareholder's return may not be an appropriate variable to absorb assetstripping behaviour. Tobin's Q can be calculated by dividing the market value of outstanding stock and debt by replacement value of production capacity. However, in this paper, we proxy Tobin's Q as the sum of book value of debt and market value of equity, divided by total assets (Chen et al., 2005; Fama and French, 2005; Aggarwal and Samwick, 2006).

The key explanatory variable of interest is the effect on company growth performance after it was partially re-acquired by the central government. We have designated this variable as SPCS as it is meant to capture the effect of the state's presence in a specific company as a major shareholder and its active involvement in company's governing board. The effect is captured by a state re-acquisition dummy variable, which is given a value of 1 if the firm has adopted the new SPCS, where the state has re-instated itself as one of the major shareholders to the firm under the Putin administration, and 0 otherwise. Russia's key shareholders were identified from

\footnotetext{
${ }^{2}$ All financial data was recorded at the end of the trading year. A Hausman test was used to determine if a fixed or a random effects model was suitable. The test showed that the null hypothesis of both estimation methods yielding similar coefficients was not rejected, hence the random effects model was used as it produced more efficient estimators

${ }^{3}$ Because of the missing observations for both at least one time period and at least one entity, we have an unbalanced dataset
} 
company annual or quarterly reports (we have also acknowledged a number of firms in which the central state held shares indirectly). Although company reports disclose all shareholders who own 5 or more percent of capital, and we classify an owner who holds more than 5 percent of company's stock as a "major shareholder", we find that Russian corporate ownership is defined by a high concentration level, where the average fraction of capital held by the principal shareholder is approximately 50 percent.

We also use several dummy variables to take account of the effect of other types of largest shareholder. For example, to capture the difference between state ownership and state re-acquisition, we introduce a dummy variable for "continuous" state ownership. We employ "continuous" state ownership variable in order to highlight the new government strategy of a central state-private investor partnership associated with the re-acquisition variable, while "continuous" state ownership simply reflects government control of the firm over the period. In this case, we recognize the central state as the continuous principal owner if the government is the only major shareholder over the period, when under the co-ownership system, the government and a private investor are both principal owners. ${ }^{4}$ Similarly, using the equivalent method, we assess the influence of regional state and foreign investor.

We also include a number of control variables to capture other firm characteristics which can influence firm performance. For example, as firm growth is affected by its size, we include the proxy of natural log of total assets (Salancik and Pfeffer, 1980; Berger and Ofek, 1995; Faccio et al., 2001). Similarly, as the level of firm debt is generally recognised as impacting firm growth, we include a commonly accepted proxy for leverage. This is the ratio of book long-term and short-term debt to

\footnotetext{
${ }^{4}$ We use the term "continuous" to signify that the state remained the largest shareholder, and SPCS was not introduced
} 
total assets (Rajan and Zingales, 1995; Lang et al., 1996; Boubakri and Cosset, 1998). As we are more interested in long-term growth than in the short-term performance of the firm, we do not include short-term debt in our leverage proxy. This measure has an advantage in that it will more accurately pick-up the effect on firm growth due to subsidised long-term loans from the state to favoured firms. These loans represent natural resource rents, which are being actively channelled to many industries (Vdovichenko and Voronina, 2006; Hanson 2007).

Finally, we include a few other measures. As the level of firm profitability is known to affect firm growth, we include the net profit before interest and taxes, divided by sales variable. This follows the method employed by Machin and Van Reenen (1993), Schranz (1993) and Loughran and Ritter (1997). In addition, as the age of a firm can affect its growth performance, we include a longevity dummy variable, which takes on the value of 1 if the firm has operated for at least 10 years prior to economic restructuring policy, and 0 otherwise. Finally, to measure the potential effect on firm growth of ownership concentration, we include a proxy of the percentage of capital owned by the largest shareholder variable.

Table 1 offers a summary description of variables used in our regression analysis.

[insert Table 1 here]

\subsection{Summary statistics}

Table 2 presents the number of firms trading on the RTS that are included in the sample over the period beginning in 1998 through to the end of 2006. For comparative purposes, the dataset is sub-divided into three periods of interest. In each period, the size of the sample is noted, and for each of the relevant variables of 
interest to our study, the sample mean, standard deviation, the maximum and minimum values and skewness are reported.

[insert Table 2 here]

The years 1998 and 1999 (Panel A) cover the ending period of the Yeltsin regime and correspond with the mature effects of its privatization policy. The subsequent period comparative statistics, reported in Panel B, covers the period from the beginning of 2000 through 2003. This period spans the formative years of the Putin regime, when the regime introduced many changes of its important corporate and industrial policy initiatives. Lastly, Panel $\mathrm{C}$ allows us to compare the relevant statistics of the more mature Putin regime over the period from the beginning of 2003 through 2006.

Panel A clearly exhibits statistics consistent with the overall poor economic performance of Yeltsin's 'laissez faire' policy. Unsurprisingly, during this period, the overall number of listed firms is low and the average Tobin's Q value is particularly low. It also picks up the August 1998 financial crisis. Panel B indicates noticeable improved corporate performance - Tobin's Q grew steadily and there was notably increased profitability. Finally, Panel $\mathrm{C}$ indicates a dramatic improvement in the Tobin's Q for a list of firms, signalling superior company performance as well as corporate growth. Interestingly, we also note a sharply increasing standard deviation of Tobin's Q variable over the given period, which signals of a wide variation in firm corporate growth performance. This may also indicate that investors' confidence in certain business sectors has increased dramatically. More importantly, we see that positive skewness has also been increasing rapidly, which demonstrates that more and more firms have exhibited superior growth performance over the period.

Significantly, the proportion of long-term debt in firm capital structure has also been increasing over time (the mean has almost doubled from 0.033 in the first 
period to 0.064 in the last period). This is consistent with the regime's policy of providing subsidized bank loans to finance targeted investment projects and firms actively employing such long-term loans in their capital structure. The size ratio gradually declined over the 1998-2006 time period. This, however, can be explained by a steady firm formation, where companies, which are not characterized by large fixed assets, entered the market (for example, service firms). Firm profitability mean has also increased from 0.080 in the initial period to 0.096 in the final period. We argue that firms generally benefited from energy sector rents being redistributed to other economic sectors under the new regime, and the new state-private copartnership system effectively preventing managers and local bureaucrats siphoning off firm profits, allowing firms to reach their growth and profitability potential. Finally, the level of ownership concentration in Russia remained high throughout the given period.

Lastly, Table 3 below summarizes the number and type of largest shareholders present across Russia's corporate sector between 1998 and 2006.

[insert Table 3 here]

In Table 3, 'state' ownership corresponds to a number of companies in which the government held a majority stake throughout the given period. ${ }^{5}$ Significant presence of state shareholder is attributed to a large number of electricity companies in the firm sample, which are the subsidiaries of the United Energy Systems of Russia (where the state is the largest investor), trading on the RTS. The increasing number of such companies is consistent with the restructuring of RAO Unified Energy Systems in 2005 and 2006.

\footnotetext{
${ }^{5}$ The identification of major shareholders mechanism is outlined in Subsection 3.1
} 
The private investors in the new SPCS firms are, in general, in the form of financial institutions or other corporations. Central state usually participates through direct or indirect holdings. For instance, from 2002 onwards, the government owned shares in many enterprises through financial institutions, in which it had partial control. It is evident from the table that since the advent of the Putin regime, the number of firms characterised by the state-private co-partnership mechanism increased dramatically. This development is consistent with the government's strategy of regaining major control over the Russian industry.

The 'non-state ownership' status describes firms without central state presence in their ownership structure. We identify four types of private owners - domestic corporation or financial institution, foreign corporation or financial institution, individuals and regional state. It is important to note that approximately 80 percent of corporate ownership structure is represented by two or more large investors (for example, the firm is owned by a foreign corporation and a domestic financial institution). Such combination of shareholders accounts for a relatively high number of domestic and foreign participants in the market. We also note the decline in regional government investor type in the latter period. This is consistent with the new policy of corporate control being transferred back to the federal government.

\section{Empirical results}

\subsection{The effect of SPCS on firm Tobin's $Q$}

Table 4 presents results from the regression analysis. From our findings (columns 1-4) we note that the state re-acquisition variable has a relatively large positive effect on firm Tobin's Q, even when we take account of trend oil prices. ${ }^{6}$ This is consistent

\footnotetext{
${ }^{6}$ See robustness test further in the text
} 
with our hypothesis that SPCS has a favourable impact on firm growth performance, as the adoption of SPCS is received positively by investors. Our result is also consistent with the findings of Chernykh (2004), who believes that private-state cooperation has improved company performance. The author attributes this to enhanced monitoring mechanism, even though such a monitoring mechanism can be accomplished in other less costly ways. Significantly, for example, continuous state ownership, regional state ownership and foreign ownership do not affect firms' Tobin's Q. Furthermore, the continuous state ownership variable coefficient is negative but small in magnitude. The negative sign can be rationalised by the fact that continuous state ownership dummy variable picks up the poor growth performance of traditional firms during the period of economic stagnation, as well as the improved performance of such firms in the later years. We also find that the regional state ownership variable has a substantial negative coefficient in regressions. However, the variable is insignificant. This finding is consistent with our hypothesis that if anything, regional government ownership hinders improved corporate growth performance.

Contrary to other studies, we find that foreign ownership has no significant effect on firm performance. However, Yudaeva et al. (2003) found that foreign firms tended to be more efficient than their domestic counterparts during Russia's privatization process. Carlin et al. (1995) found that firms in Russia, Czech Republic, Hungary and Bulgaria benefited from major foreign-run investment programs during the early transition period. Smith et al. (1997) had similar results for Slovenia. But domestic and foreign entities should find it equally difficult to maintain an advanced corporate governance code in an environment characterised by insecure property rights. This is consistent with our results. 
We find that firm's long-term debt is positively associated with its Tobin's Q. The magnitude of the long-term debt variable coefficient has an average of 1.358 , and the variable is significant at 1 percent level. With the advent of the Putin regime, financial institutions are used as conduits for subsidized loans, where state subsidies take the form of direct funds as well as subsidised credit interest rates or credit guarantees (Vedev, 2008). Thus we should expect a positive effect on firm growth performance the higher the level of long-term bank loans, which is consistent with our results. This investment strategy is also consistent with Russia's tradition. The present system has the Central Bank of Russia regulating all commercial banks through a system of licensing investment funds to every credit institution. Consequently, targeted (especially large) firms are now financed through government-influenced loans. Our results find that firm size, which is measured by the natural log of total assets, does not affect firm growth performance. This finding highlights that while larger fixed assets (which account for the bigger proportion of assets in our size measure) generate higher future cash flows, they are also subject to higher potential hold-up costs.

We find that profitability has a positive effect on Tobin's Q. This is consistent with findings of many studies documenting a favourable market reaction to positive earnings announcements. For instance, Barberis et al. (1998) and Daniel et al. (1998) show that investors tend to over-react to a series of good news, even if only in the short-term period. The positive effect of earnings on growth is found to be more widespread in countries with a well-defined legal system, which is characterized by superior insider trading regulations and strong shareholder protection (DeFond et al., 2007). Bhattacharya et al. (2000) believe that unrestricted insider trading can lead to all information being absorbed into stock prices prior to the actual announcement, 
hence no positive effect of earnings on growth. But in the Russian case, our positive finding may be attributed to the fact that the Russian capital market is freer of insider dealing because of the SPCS governing mechanism.

Our results also indicate that the degree of ownership concentration has a significant but slightly positive effect on firm Tobin's Q. The finding is consistent with a view that ownership concentration may act to prevent wealth tunnelling. Consistently, Xu and Wang (1999) also find a strong positive correlation between ownership concentration and profitability in China, and Joh (2003), using a large dataset of 5,829 Korean firms during the 1993-1997 period, finds that low ownership concentration tends to lead to low profitability.

Our results show that Tobin's Q measure of performance is adversely affected by firm longevity. The longevity parameter estimate is both large $(-0.954)$ and significant. This, as it first appears, may be unsurprising, given that 'old' firms generally tend to exhaust any growth opportunity (Evans, 1987a, 1987b; Variyam and Kraybill, 1992). However, as many 'old' Russian enterprises (for instance, utility) received substantial investment funds over the sample period, the negative effect is nonetheless surprising. But it can be rationalised by the fact that longer-lived firm dummy variable in the sample was adversity impacted by the early disastrous privatisation process and August 1998 crisis.

[insert Table 4 here]

\subsection{Robustness checks}

As a first robustness check, we incorporate the natural log of oil prices variable to measure the direct effect of increased energy prices on Tobin's Q for the whole corporate sector portfolio over the sample period. Unsurprisingly, oil prices had a 
significant impact. The variable coefficient in column (5) has a value of 0.578 and is statistically significant at 1 percent level. We also note the increase in R-squared and Wald chi-squared values when oil prices are included. Significantly, we find that oil prices do not explain the whole improved Tobin's Q statistic, and the oil price effect inclusion only resulted in a small fall of state re-acquisition coefficient size and its level of significance. Consequently, the SPCS plays an important role in Russian corporate growth.

We next incorporate a time trend effect. From column (6) we see that with the time effect inclusion, the state re-acquisition variable is still positive and statistically significant at 5 percent level, even when time dummy variables are significant. ${ }^{7}$ The only noticeable effect is, once again, an increase in R-squared and Wald chi-squared values.

Next, one must address the problem of endogeneity. In that, we must determine that the new corporate co-partnership system leads to higher Tobin's Q, and that the state does not simply target, or 'cherry-pick' more profitable firms. It may be useful to establish whether companies, which were partially re-acquired by the state in period $\mathrm{t}$ exhibited high Tobin's $\mathrm{Q}$ prior to acquisition in period $\mathrm{t}-1$. Table 5 shows the number of companies partially re-acquired by the state across nine major economic sectors. First, we note that the state did not primarily target energy sector firms, which are undoubtedly characterized by the highest growth potential given continually increasing energy prices during the period. It can be seen from the table that the state also re-acquired a significant number of utility and manufacturing firms. More importantly, when we compare firms' Tobin's Q in the period of acquisition with their Tobin's Q in the period preceding it, we find that in most cases company

\footnotetext{
${ }^{7}$ Time trend is represented by year dummy variables
} 
Tobin's Q was substantially lower before SPCS was introduced. These findings signal that the state did not merely pursue a self-enrichment agenda by acquiring most profitable firms.

\section{[insert Table 5 here]}

Significantly, in order to determine whether the adoption of the state-private coownership mechanism in t-1 period leads to higher Tobin's Q in the following period, we repeat the regression analysis, substituting state re-acquisition variable with its lagged term, which now serves as an instrumental variable. Thus we employ a TwoStage Least Squares (2SLS-IV) instrumental variable approach to address the problem of endogeneity, which is similar to Aschauer (1989) method of estimating causation between public capital and productivity. ${ }^{8}$ Column (7), Table 4 shows that the coefficient of this variable has increased to 0.568 and now is statistically significant at 1 percent level. Therefore, it is believed that firms tend to exhibit higher Tobin's Q by adopting the SPCS and the state does not ultimately target high-value companies to engage in predatory behaviour.

Finally, in Table 6 we replace the Tobin's Q estimator with the second, and then a third proxy. The second proxy (TQ1) is the market value of all shares plus book value of long term debt and the difference between current liabilities and current assets, divided by the total value of firm's assets (Chung and Pruitt, 1994). The third proxy (TQ2) serves is a variation of the first proxy - it is the annual change in the above variable (delta Tobin's Q). This variation seeks to capture the sensitivity of the

\footnotetext{
${ }^{8}$ Fearon and Laitin (2003) also address the endogeneity problem by employing lagged value of per capita GDP as explanatory variable when establishing a relationship between civil war and GDP
} 
corporate value with respect to change in independent variables. For TQ2, the estimation equation is

$$
d Y_{\text {it }}=\beta_{0}+\beta_{1} d X_{1 i t}+\beta^{\prime}{ }_{2} d X_{2 i t}+\varepsilon_{\text {it }}
$$

It can be seen from the table that the size variable is significant for both TQ1 and TQ2, while profitability variable becomes insignificant for TQ1. We also note a largely reduced R-squared and Wald chi-squared value for TQ2, where ownership concentration and firm longevity no longer affect company growth performance. Nevertheless, under all new proxies, our analysis seems to indicate that the SPCS has a positive impact on firm Tobin's Q, which is consistent with our initial findings.

[insert Table 6 here]

\section{Conclusion and implications}

In this paper we argue that up to the recent financial crisis, the significantly improved growth performance of the Russian corporate sector is partially attributable to the adoption of the co-partnership system between the state and private investors. We argue that the SPCS acts to constrain opportunistic behaviour of corporate managers and local bureaucrats, both of whom have the propensity to liquidate assets before it is profitable to do so. Their opportunistic behaviour not only lies in the fact that Russia has ineffective property rights system, but also because corporate assets are often heavily subsidised.

Our findings show that the new state-private co-partnership system has a positive impact on firm growth performance. These results indicate that private investors view central state's commitments to ensuring that investors receive their expected return as 
credible. In other words, while it can be suggested that the federal state may have the same non-optimal investment horizons as corporate managers or local bureaucrats in a relatively unstable political regime, the findings in this paper demonstrate that this is not the case. Private investors do not anticipate the central government to engage in predatory behaviour, and recognise SPCS as an effective substitute to a poorlydefined property rights system.

Further research issues, arising from the main proposition of this paper on the efficiency of the co-partnership system, should in general concentrate on a more "micro" level, for example, on measuring the impact on growth due to the fortuitous rise in energy prices. In that, one can extend the analysis by updating the dataset to include the period characterised by falling energy prices, and relate their adverse effects on the corporate sector falling growth rates across industries. 


\section{References}

Aggarwal, R. K. and Samwick, A. A. 2006: Empire-builders and shirkers: investment, firm performance, and managerial incentives. Journal of Corporate Finance 12: 489515.

Alchian, A. A. 1977: Economic Forces at Work. Liberty Press: Indianapolis.

Alchian, A.A. and Allen, W.R. 1977: Exchange and Production: Competition, Coordination, and Control. Wadsworth Publishing Company, Inc.: California.

Alexeev, M. 1999: The effect of privatisation on wealth distribution in Russia. Economics of Transition 7: 449-465.

Aschauer, D.A. 1989: Is public expenditure productive?. Journal of Monetary Economics 23: 177-200.

Bahry, D. 2005: The new federalism and the paradoxes of regional sovereignty in Russia. Comparative Politics 37: 127-146.

Barberis, N., Shleifer, A. and Vishny, R. 1998: A model of investor sentiment. Journal of Financial Economics 49: 307-343.

Berger, P.G. and Ofek, E. 1995: Diversification's effect on firm value. Journal of Financial Economics 37: 39-65.

Bhattacharya, U., Daouk, H., Jorgenson, B. and Kehr, C.H. 2000: When an event is not and event: the curious case of an emerging market. Journal of Financial Economics 55: 69-101.

Black, B.S., Kraakman, R. and Tarassova, A.S. 2000: Russian privatisation and corporate governance: what went wrong?. Stanford Law Review 52: 1731-1808.

Boubakri, N. and Cosset, J.C. 1998: The financial and operating performance of newly privatized firms: evidence from developing countries. The Journal of Finance 53: 1081-1110.

Braguinsky, S. and Yavlinsky, G. 2000: Incentives and Institutions: The Transition to a Market Economy in Russia. Princeton University Press: Princeton, N.J.

Broadman, H.G., 1999: Comments on ownership and control of Russian industry. Paper prepared for Conference on Corporate Governance in Russia, Moscow.

Carlin, W., Van Reenen, J. and Wolfe, T. 1995: Enterprise restructuring in early transition: the case study evidence from Central and Eastern Europe. Economics of Transition 3: 427-458. 
Chen, H., Frank, M. Z. and Wu, O.Q., 2005: What actually happened to the inventories of American companies between 1981 and 2000?. Management Science 51: 1015-1031.

Chernykh, L. 2004: New evidence on state control and corporate performance in Russia. http://www.fma.org/Chicago/Papers/State_control_Russia.pdf

Chung, K. H and Pruitt, S.W. 1994: A simple approximation of Tobin's Q. Financial Management 23: 70-74.

Clarke, S. and Kabalina, V. (1995): Privatisation and the struggle for control of the enterprise. In Lane, D. (eds.). Russia in Transition: Politics, Privatisation and Inequality. Longman Group UK Limited: Essex, pp. 142-158.

Coase, R.H. 1960: The problem of social cost. Journal of Law and Economics 3: 144.

Coffee, J.C. 1999 : Privatization and corporate governance: the lessons from securities market failure. Journal of Corporate Law 25: 1-39.

Conditions in Russia at the Outset of the Yeltsin and Clinton Administration. Russia's Road to Corruption, United States House of Representatives $106^{\text {th }}$ Congress http://www.fas.org/news/russia/part02.htm

Daniel, K., Hirshleifer, D. and Subrahmanyam, A. 1998: Investor psychology and security market under-and overreactions. The Journal of Finance 53: 1839-1885.

Debardeleben, J. 1999: Attitudes towards privatisation in Russia. Europe-Asia Studies 51: 447-465.

DeFond, M., Hung, M. and Trezevant, R. 2007: Investor protection and the information content of annual earnings announcements: international evidence. Journal of Accounting and Economics 43: 37-67.

Demsetz, H. 1967: Toward a theory of property rights. The American Economic Review 57: 347-359.

Dininio, P. and Orttung, R. 2005: Explaining patterns of corruption in the Russian regions. World Politics 57, 500-529.

Dyck, A. 2002: The Hermitage fund: media and corporate governance in Russia. Working Paper No. N2-703-010, Harvard Business School, Boston.

Evans, D. S. 1987: Tests of alternative theories of firm growth. The Journal of Political Economy 95: 657-674.

Evans, D. S. 1987: The relationship between firm growth, size, and age: estimates for 100 manufacturing industries. The Journal of Industrial Economics 35: 567-581. 
Faccio, M., Lang, L.H.P. and Young, L. 2001: Dividends and expropriation. American Economic Review 91: 54-78.

Fama, E.F. and French, K.R. 2005: Financing decisions: who issues stock?. Journal of Financial Economics 76: 549-582.

Fearon, J.D. and Laitin, D.D. 2003.:Ethnicity, insurgency and Civil War. American Political Science Review 97: 75-90.

Fox, M.B. and Heller, M.A. 2000: Lessons from fiascos in Russian corporate governance. Working Paper No. 99-012, University of Michigan Law School and William Davidson Institute.

Goldman, M.I. 2003: The Piratisation of Russia: Russian Reform Goes Awry. Routledge: London.

Greenspan, A. 2008: The Age of Turbulence. Penguin Group: New York.

Gregory, P. and Schrettl, W. (2004): Administration and reform of the Russian economy. In Hardt, J.P. (eds.). Russia's Uncertain Economic Future. M.E. Sharpe Inc.: NY, pp. 81-96.

Guriev, S. and Rachinsky, A. 2005: The role of oligarchs in Russian capitalism. Journal of Economic Perspectives 19: 131-150.

Hanson, P. 2007: The Russian economic puzzle: going forward, backwards or sideways?. International Affairs 83: 869-889.

Harris, M. and Raviv, A. 1991: The theory of capital structure. Journal of Finance 46: 297-355.

Hoff, K. and Stiglitz, J.E. 2004: After the big bang? Obstacles to the emergence of the rule of law in post-communist societies. The American Economic Review 94: 753763.

Hoffman, D.E. 2002: The Oligarchs: Wealth and Power in the New Russia. Public Affairs: New York.

Intriligator, M.D. 1994: Privatisation in Russia has led to criminalisation. Australian Economic Review 27: 4-14.

Intriligator, M.D. 1998: Democracy in reforming collapsed communist economies: blessing or curse?, Contemporary Economic Policy 16: 241-246.

Ivanenko, V. 2005: The importance of being normal. Russia in Global Affairs 4: 1-6.

Joh, S.W. 2003: Corporate governance and firm profitability: evidence from Korea before the economic crisis. Journal of Financial Economics 68: 287-322. 
Klein, B., Crawford, R.G. and Alchian, A.A. 1978: Vertical integration, appropriable rents, and the competitive contracting process. Journal of Law and Economics 21: 297-326.

Kuznetsov, P. and Muravyev, A. 2001: Ownership concentration and firm performance in Russia: the case of blue chips of the stock market. Acta Oeconomica 51: 469-488.

Lang, L. Ofek, E. and Stulz, R.M. 1996: Leverage, investment, and firm growth. Journal of Financial Economics 40: 3-29.

Lazareva, O., Rachinsky, A. and Stepanov, S. 2007: A survey of corporate governance in Russia. Working Paper No. 103, CEFIR/NES Working Paper Series, Centre for Economic and Financial Research at New Economic School, Russia.

Loughran, T. and Ritter, J.R. 1997: The operating performance of firms conducting seasoned equity offerings. The Journal of Finance 52: 1823-1850.

Machin, S. and Van Reenen, J. 1993: Margins and the business cycle: evidence from UK manufacturing firms. The Journal of Industrial Economics 41: 29-50.

Nellis, J. 1999: Time to rethink privatisation in transition economies? Discussion Paper Number No. 38, International Finance Corporation, Washington, D.C.

Porshakov, S., Mau, V., Grigoriev, L. and Salikhov, M. 2006: Improving corporate governance in Russia and the EU. Russia in Global Affairs, http://eng.globalaffairs.ru/region-economics/regsel/date2006-05-08.html

Puffer, S.M. and McCarthy, D.J. 2003: The emergence of corporate governance in Russia. Journal of World Business 38: 284-298.

Rajan, R.G. and Zingales, L. 1995: What do we know about capital structure: some evidence from international data. The Journal of Finance 50: 1421-1460.

Rapaczynski, A. 1996: The roles of the state and the market in establishing property rights. The Journal of Economic Perspectives 10: 87-103.

Robinson, N. 2002: Russia: A State of Uncertainty. Routledge: London.

Rock, C.P.and Solodkov, V. 2001: Monetary policies, banking, and trust in changing institutions: Russia's transition in the 1990s. Journal of Economic Issues 35: 451-458.

Ross, C. 2004: Russian Politics Under Putin. Manchester University Press: Manchester.

Salancik, G.R. and Pfeffer, J. 1980: Effects of ownership and performance on executive tenure in U.S. corporations. The Academy of Management Journal 23: 653664. 
Schranz, M. 1993: Takeovers improve firm performance: evidence from the banking industry. The Journal of Political Economy 101: 299-326.

Shleifer, A. and Treisman, D. 2005: A normal country: Russia after communism. Journal of Economic Perspectives 19: 151-174.

Shleifer, A. and Vishny, R.W. 1998: The Grabbing Hand: Government Pathologies and Their Cures. Harvard University Press: Cambridge, MA.

Smith, S.C., Cin, B.C. and Vodopivec, M. 1997: Privatisation incidence, ownership forms, and firm performance: evidence from Slovenia. Journal of Comparative Economics 25: 158-179.

Sonin, C. 2000: Inequality, property rights, and economic growth in transition economies: theory and Russian evidence. Working Paper No. 2K/02. EERC Research Network, Russia.

Spicer, A. and Pyle, W. 2003: Institutions and the vicious circle of distrust in the Russian household deposit market 1992-1999. Working Paper No. 588, William Davidson Institute, Michigan.

Stiglitz, J.E. 2002: Globalisation and its Discontents. W.W. Norton: New York.

Thomson, W. (2002): The present and future of banking reform. In: Lane, D. (eds.). Russian Banking Evolution, Problems and Prospects. Edward Elgar: Cheltenham, pp. 56-78.

Tompson, W. 2005: Putting Yukos in perspective. Post-Soviet Affairs 21: 159-181.

Variyam, J.N. and Kraybill, D.S. 1992: Empirical evidence on determinants of firm growth. Economic Letters 38: 31-36.

Vdovichenko, A.G. and Voronina, V.G. 2006: Monetary policy rules and their application in Russia. Research in International Business and Finance 20: 145-162.

Vedev, A. 2008: Revising the quality of growth. Economic Monthly, Bank of Moscow http://www.vedi.ru/bank_sys/bank2808_e.pdf

Williamson, O.E. 1979: Transaction-cost economics: the governance of contractual relations. Journal of Law and Economics 22: 233-261.

Wintrobe, R. 1998. Privatisation, the market for corporate control, and capital flight from Russia. The World Economy 21: 603-611.

Woodruff, D. 2005: Kogda nel'zya no ochen' khochetsya: korni nestabil'nosti sobstvennosti v Rossii. Mimeo, Harvard University, 21 June

http://personla.lse.ac.uk/woodruff/_priavte/materials/kogdanelzia.pdf

$\mathrm{Xu}, \mathrm{X}$. and Wang, Y. 1999: Ownership structure and corporate governance in Chinese stock companies. China Economic Review 10: 75-98. 
Yakovlev, A. and Osteuropa, F. 2003. Corporate Governance in Russia: Formal Rules and Real Incentives of Economic Agents. Institute for Industrial and Market Studies at HSE Moscow

http://www2.wiwi.hu-berlin.de/institute/im/_html/tagung/Yakovlev.pdf

Yudaeva, K., Kozlov, K., Melentieva, N. and Ponomareva, N. 2003: Does foreign ownership matter?: the Russian experience. Economics of Transition 11: 383-409. 
Table 1. Definition of variables

\begin{tabular}{|c|c|}
\hline Variable & $\begin{array}{l}\text { Description } \\
\end{array}$ \\
\hline Tobin's Q & $\begin{array}{l}\left(\mathrm{V}_{\mathrm{t}}+\mathrm{LTD} \mathrm{T}_{\mathrm{t}}+\mathrm{STDt}\right) / \mathrm{A}_{\mathrm{t}} \text {. The market value of equity plus book value of debt, } \\
\text { divided by total assets (Fama and French, 2005; Chen et al., 2005; Aggarwal } \\
\text { and Samwick, 2006). }\end{array}$ \\
\hline Size & $\mathrm{LnA}_{\mathrm{t}}$. The natural $\log$ of total assets. \\
\hline Long-term debt & $\mathrm{LTD}_{\mathrm{t}} / \mathrm{A}_{\mathrm{t}}$. The ratio of book value of long-term debt to total assets. \\
\hline Profitability & $\begin{array}{l}E_{t} / \text { Sales }_{t} \text {. The ratio of earnings before interest and taxes to sales (Machin and } \\
\text { Van Reenen, 1993; Schranz, 1993; Loughran and Ritter, 1997). }\end{array}$ \\
\hline $\begin{array}{l}\text { Ownership } \\
\text { concentration }\end{array}$ & Fraction of capital owned by the largest shareholder, expressed in $\%$. \\
\hline Longevity & Equals 1 if the firm had existed during the Soviet era; 0 otherwise. \\
\hline $\begin{array}{l}\text { Continuous state } \\
\text { ownership }\end{array}$ & $\begin{array}{l}\text { Equals } 1 \text { if the firm is owned by the central state directly or indirectly } \\
\text { throughout the period; } 0 \text { otherwise. }\end{array}$ \\
\hline $\begin{array}{l}\text { State re- } \\
\text { acquisition }\end{array}$ & $\begin{array}{l}\text { Equals } 1 \text { if the state has re-established its position as firm's major shareholder } \\
\text { during the Putin regime; } 0 \text { otherwise. }\end{array}$ \\
\hline $\begin{array}{l}\text { Regional state } \\
\text { ownership }\end{array}$ & Equals 1 if regional state is firm's main shareholder; 0 otherwise. \\
\hline $\begin{array}{l}\text { Foreign } \\
\text { ownership }\end{array}$ & $\begin{array}{l}\text { Equals } 1 \text { if foreign corporation/financial institution is firm's main shareholder; } \\
0 \text { otherwise. }\end{array}$ \\
\hline
\end{tabular}


Table 2. Summary statistics for firms trading on RTS between 1998 and 2006

\begin{tabular}{|c|c|c|c|c|c|c|}
\hline Variable & No. of obs & Mean & $\begin{array}{l}\text { Standard } \\
\text { deviation }\end{array}$ & Min & Max & Skewness \\
\hline \multicolumn{7}{|c|}{ Panel A: 1998-1999 } \\
\hline $\begin{array}{l}\text { Tobin's Q } \\
\left(\mathrm{V}_{\mathrm{t}}+\mathrm{LTD}_{\mathrm{t}}+\mathrm{STD}_{\mathrm{t}}\right) / \mathrm{A}_{\mathrm{t}}\end{array}$ & 165 & 0.357 & 0.490 & 0.003 & 3.644 & 3.05 \\
\hline Size $\left(\operatorname{Ln} A_{t}\right)$ & 267 & 0.669 & 0.179 & 0.066 & 0.976 & -0.753 \\
\hline Long-term debt $\left(\mathrm{LTD}_{\mathrm{t}} / \mathrm{A}_{\mathrm{t}}\right)$ & 269 & 0.033 & 0.084 & 0.000 & 0.598 & 3.679 \\
\hline Profitability $\left(E_{t} /\right.$ Sales $\left._{t}\right)$ & 139 & 0.080 & 0.418 & -3.263 & 0.805 & -5.050 \\
\hline Ownership concentration $(\%)$ & 270 & 41.304 & 17.679 & 7.000 & 99.990 & 0.442 \\
\hline
\end{tabular}

Panel B: 2000-2002

\begin{tabular}{lcccccc}
\hline $\begin{array}{l}\text { Tobin's Q } \\
\left(\mathrm{V}_{\mathrm{t}}+\mathrm{LTD}_{\mathrm{t}}+\mathrm{STD}_{\mathrm{t}}\right) / \mathrm{A}_{\mathrm{t}}\end{array}$ & 379 & 0.432 & 0.555 & 0.001 & 4.303 & 3.693 \\
Size $\left(\mathrm{LnA}_{\mathrm{t}}\right)$ & 513 & 0.630 & 0.207 & 0.00002 & 0.969 & -0.950 \\
Long-term debt $\left(\mathrm{LTD}_{\mathrm{t}} / \mathrm{A}_{\mathrm{t}}\right)$ & 519 & 0.052 & 0.112 & 0.000 & 0.694 & 5.923 \\
Profitability $\left(\mathrm{E}_{\mathrm{t}} /\right.$ Sales $\left._{\mathrm{t}}\right)$ & 457 & 0.093 & 0.327 & -5.159 & 0.904 & 17.380 \\
Ownership concentration $(\%)$ & 512 & 43.363 & 17.009 & 6.000 & 99.990 & 0.334 \\
\hline
\end{tabular}

Panel C: 2003-2006

\begin{tabular}{lcccccc}
\hline $\begin{array}{l}\text { Tobin's Q } \\
\left(\mathrm{V}_{\mathrm{t}}+\mathrm{LTD}_{\mathrm{t}}+\mathrm{STD}_{\mathrm{t}}\right) / \mathrm{A}_{\mathrm{t}}\end{array}$ & 1264 & 0.844 & 1.082 & 0.001 & 17.931 & 4.778 \\
Size $\left(\mathrm{LnA}_{\mathrm{t}}\right)$ & 1655 & 0.626 & 0.232 & 0.0001 & 0.999 & -0.780 \\
Long-term debt $\left(\mathrm{LTD}_{\mathrm{t}} / \mathrm{A}_{\mathrm{t}}\right)$ & 1671 & 0.064 & 0.121 & 0.000 & 0.721 & 2.573 \\
Profitability $\left(\mathrm{E}_{\mathrm{t}} /\right.$ Sales $\left._{\mathrm{t}}\right)$ & 754 & 0.096 & 0.312 & -3.980 & 0.980 & 11.475 \\
Ownership concentration $(\%)$ & 1621 & 47.751 & 19.101 & 6.000 & 99.990 & 0.437 \\
\end{tabular}


Table 3. Major shareholders of firms trading on RTS during 1998-2006

\begin{tabular}{llllllllll}
\hline $\begin{array}{l}\text { State ownership / } \\
\text { co-ownership }\end{array}$ & $\mathbf{1 9 9 8}$ & $\mathbf{1 9 9 9}$ & $\mathbf{2 0 0 0}$ & $\mathbf{2 0 0 1}$ & $\mathbf{2 0 0 2}$ & $\mathbf{2 0 0 3}$ & $\mathbf{2 0 0 4}$ & $\mathbf{2 0 0 5}$ & $\mathbf{2 0 0 6}$ \\
\hline State & 64 & 74 & 71 & 69 & 65 & 59 & 63 & 80 & 82 \\
SPCS & 6 & 9 & 17 & 20 & 20 & 29 & 25 & 26 & 45 \\
\hline $\begin{array}{l}\text { Non-state multi- } \\
\text { ownership }\end{array}$ & & & & & & & & & \\
\hline $\begin{array}{l}\text { Domestic } \\
\text { firm/financial } \\
\text { institution }\end{array}$ & 15 & 41 & 53 & 54 & 63 & 74 & 73 & 70 & 72 \\
$\begin{array}{l}\text { Foreign } \\
\text { firm/financial } \\
\text { institution }\end{array}$ & 14 & 27 & 21 & 19 & 27 & 24 & 25 & 27 & 34 \\
$\begin{array}{l}\text { Individual } \\
\text { Regional government }\end{array}$ & 8 & 11 & 11 & 11 & 10 & 7 & 4 & 3 & 3 \\
\hline
\end{tabular}


Table 4. The effect of SPCS and other explanatory variables on firms' Tobin's Q

\begin{tabular}{|c|c|c|c|c|c|c|c|}
\hline Variable & 1 & 2 & 3 & 4 & 5 & 6 & 7 (2SLS-IV) \\
\hline Size & $\begin{array}{c}0.180 \\
(0.155)\end{array}$ & $\begin{array}{c}0.176 \\
(0.154)\end{array}$ & $\begin{array}{c}0.161 \\
(0.154)\end{array}$ & $\begin{array}{c}0.161 \\
(0.154)\end{array}$ & $\begin{array}{c}0.183 \\
(0.147)\end{array}$ & $\begin{array}{c}0.032 \\
(0.144)\end{array}$ & $\begin{array}{c}0.155 \\
(0.129)\end{array}$ \\
\hline Long-term debt & $\begin{array}{c}1.343^{* * * *} \\
(0.256)\end{array}$ & $\begin{array}{c}1.374 * * * \\
(0.254)\end{array}$ & $\begin{array}{c}1.361 * * * \\
(0.255)\end{array}$ & $\begin{array}{c}1.354 * * * \\
(0.255)\end{array}$ & $\begin{array}{l}1.082^{* * * *} \\
(0.245)\end{array}$ & $\begin{array}{c}0.633 * * * \\
(0.234)\end{array}$ & $\begin{array}{c}1.501 * * * \\
(0.247)\end{array}$ \\
\hline Profitability & $\begin{array}{c}0.018 * * \\
(0.007)\end{array}$ & $\begin{array}{c}0.018 * * \\
(0.007)\end{array}$ & $\begin{array}{c}0.019 * * \\
(0.007)\end{array}$ & $\begin{array}{l}0.019 * * \\
(0.007)\end{array}$ & $\begin{array}{c}0.016 * * \\
(0.007)\end{array}$ & $\begin{array}{l}0.020 * * * \\
(0.008)\end{array}$ & $\begin{array}{c}0.012 \\
(0.014)\end{array}$ \\
\hline $\begin{array}{l}\text { Ownership } \\
\text { concentration }\end{array}$ & $\begin{array}{c}0.008 * * * \\
(0.002)\end{array}$ & $\begin{array}{c}0.008 * * * \\
(0.002)\end{array}$ & $\begin{array}{c}0.008^{* * * *} \\
(0.002)\end{array}$ & $\begin{array}{c}0.008 * * * \\
(0.002)\end{array}$ & $\begin{array}{c}0.004 * * \\
(0.002)\end{array}$ & $\begin{array}{c}0.003 * * \\
(0.001)\end{array}$ & $\begin{array}{c}0.009 * * * \\
(0.002)\end{array}$ \\
\hline Firm longevity & $\begin{array}{c}-0.954 * * * \\
(0.115)\end{array}$ & $\begin{array}{c}-0.972 * * * \\
(0.116)\end{array}$ & $\begin{array}{c}-0.947 * * * \\
(0.116)\end{array}$ & $\begin{array}{c}-0.942 * * * \\
(0.116)\end{array}$ & $\begin{array}{c}-0.756^{* * *} \\
(0.114)\end{array}$ & $\begin{array}{c}-0.562 * * * \\
(0.128)\end{array}$ & $\begin{array}{c}-0.917 * * * \\
(0.083)\end{array}$ \\
\hline $\begin{array}{l}\text { Continuous state } \\
\text { ownership }\end{array}$ & $\begin{array}{l}-0.043 \\
(0.072)\end{array}$ & & & & & & \\
\hline State re-acquisition & & $\begin{array}{c}0.199 * * * \\
(0.074)\end{array}$ & & & $\begin{array}{c}0.140 * * \\
(0.071)\end{array}$ & $\begin{array}{c}0.138 * * \\
(0.065)\end{array}$ & $\begin{array}{c}0.568 * * * \\
(0.156)\end{array}$ \\
\hline $\begin{array}{l}\text { Regional state } \\
\text { ownership }\end{array}$ & & & $\begin{array}{l}-0.205 \\
(0.177)\end{array}$ & & & & \\
\hline Foreign ownership & & & & $\begin{array}{c}0.102 \\
(0.106)\end{array}$ & & & \\
\hline Oil price & & & & & $\begin{array}{c}0.578 * * * \\
(0.054)\end{array}$ & & \\
\hline Time effects & No & No & No & No & No & Yes & No \\
\hline Constant & $\begin{array}{c}1.124 * * * \\
(0.156)\end{array}$ & $\begin{array}{l}1.101 * * * \\
(0.154)\end{array}$ & $\begin{array}{c}1.119 * * * \\
(0.155)\end{array}$ & $\begin{array}{c}1.094 * * * \\
(0.157)\end{array}$ & $\begin{array}{c}-0.167 \\
(0.187)\end{array}$ & $\begin{array}{c}1.754 * * * \\
(0.159)\end{array}$ & $\begin{array}{c}0.887 * * * \\
(0.133)\end{array}$ \\
\hline No. of observations & 1064 & 1064 & 1064 & 1065 & 1064 & 1064 & 1017 \\
\hline R-squared & 0.181 & 0.178 & 0.176 & 0.180 & 0.257 & 0.283 & 0.149 \\
\hline Wald chi -squared & $135.44 * * *$ & $141.00 * * *$ & $134.17 * * *$ & $133.76 * * *$ & $376.24 * * *$ & $528.75 * * *$ & $213.50 * * *$ \\
\hline
\end{tabular}

$*, * *$ and $* * *$ denote significance at the 10,5 and 1 percent level, respectively 
Table 5. The comparison of firm Tobin's Q prior and during the re-acquisition period

\begin{tabular}{lcccc}
\hline Industry & Firms acquired & $\mathbf{T Q}_{\mathbf{t}-\mathbf{1}}>\mathbf{T} \mathbf{Q}_{\mathbf{t}}$ & $\mathbf{T Q}_{\mathbf{t}-\mathbf{1}}<\mathbf{T} \mathbf{Q}_{\mathbf{t}}$ & $\mathbf{N} / \mathbf{A}$ \\
\hline Utility & 22 & 2 & 18 & 2 \\
Metallurgy & 5 & 0 & 3 & 2 \\
Energy & 9 & 0 & 8 & 1 \\
Food production & 1 & 1 & 0 & 0 \\
Manufacturing & 20 & 1 & 17 & 2 \\
Communications & 2 & 0 & 1 & 1 \\
Retail & 2 & 1 & 1 & 0 \\
Transport & 3 & 0 & 2 & 1 \\
Banking & 1 & 0 & 0 & 1 \\
\hline
\end{tabular}


Table 6

The effect of SPCS and other explanatory variables on firms' Tobin's Q1 and TQ2

\begin{tabular}{|c|c|c|c|c|c|c|c|c|}
\hline Variable & TQ1 (1) & TQ1 (2) & TQ1 (3) & TQ1 (4) & TQ2 (1) & TQ2 (2) & TQ2 (3) & TQ2 (4) \\
\hline \multirow[t]{2}{*}{ Size } & $0.812 * * *$ & $0.810 * * *$ & $0.794 * * *$ & $0.795 * * *$ & $0.337 * *$ & $0.354 * *$ & $0.337 * *$ & $0.339 * *$ \\
\hline & $(0.146)$ & $(0.146)$ & $(0.145)$ & $(0.145)$ & $(0.170)$ & $(0.170)$ & $(0.170)$ & $(0.170)$ \\
\hline \multirow[t]{2}{*}{ Long-term debt } & $1.094 * * *$ & $1.117 * * *$ & $1.111 * * *$ & $1.102 * * *$ & $1.347 * * *$ & $1.364 * * *$ & $1.346 * * *$ & $1.357 * * *$ \\
\hline & $(0.245)$ & $(0.243)$ & $(0.243)$ & $(0.244)$ & $(0.273)$ & $(0.272)$ & $(0.273)$ & $(0.273)$ \\
\hline \multirow[t]{2}{*}{ Profitability } & -0.001 & -0.001 & -0.001 & -0.001 & $0.032 * * *$ & $0.032 * * *$ & $0.032 * * *$ & $0.032 * * *$ \\
\hline & $(0.002)$ & $(0.002)$ & $(0.002)$ & $(0.002)$ & $(0.009)$ & (0.009) & $(0.009)$ & $(0.009)$ \\
\hline Ownership & $0.007 * * *$ & $0.007 * * *$ & $0.007 * * *$ & $0.007 * * *$ & 0.002 & 0.002 & 0.002 & 0.002 \\
\hline concentration & $(0.002)$ & $(0.002)$ & $(0.002)$ & $(0.002)$ & $(0.002)$ & $(0.002)$ & $(0.002)$ & $(0.002)$ \\
\hline \multirow[t]{2}{*}{ Firm longevity } & $-0.970 * * *$ & $-0.986 * * *$ & $-0.965 * * *$ & $-0.959 * * *$ & 0.037 & 0.028 & 0.038 & 0.033 \\
\hline & $(0.108)$ & $(0.110)$ & $(0.110)$ & (0.109) & $(0.086)$ & $(0.086)$ & $(0.086)$ & $(0.086)$ \\
\hline \multirow[t]{2}{*}{ Continuous state ownership } & -0.043 & & & & 0.009 & & & \\
\hline & $(0.068)$ & & & & $(0.056)$ & & & \\
\hline \multirow[t]{2}{*}{ State re-acquisition } & & $0.146^{* *}$ & & & & $0.138 * *$ & & \\
\hline & & $(0.070)$ & & & & $(0.069)$ & & \\
\hline \multirow[t]{2}{*}{ Regional state ownership } & & & -0.217 & & & & -0.045 & \\
\hline & & & $(0.162)$ & & & & $(0.184)$ & \\
\hline \multirow{2}{*}{ Foreign ownership } & & & & 0.111 & & & & -0.063 \\
\hline & & & & $(0.101)$ & & & & $(0.089)$ \\
\hline \multirow[t]{2}{*}{ Constant } & $0.615 * * *$ & $0.595 * * *$ & $0.608 * * *$ & $0.583 * * *$ & 0.124 & 0.117 & 0.129 & $0.141^{*}$ \\
\hline & $(0.144)$ & $(0.142)$ & $(0.142)$ & $(0.144)$ & $(0.085)$ & $(0.080)$ & $(0.078)$ & $(0.082)$ \\
\hline No. of observations & 1088 & 1088 & 1088 & 1089 & 807 & 807 & 807 & 808 \\
\hline R-squared & 0.202 & 0.198 & 0.199 & 0.202 & 0.047 & 0.051 & 0.047 & 0.047 \\
\hline Wald chi-squared value & $144.06 * * *$ & $146.32 * * *$ & $143.61 * * *$ & $142.73 * * *$ & $40.04 * * *$ & $44.17 * * *$ & $40.08 * * *$ & $40.59 * * *$ \\
\hline
\end{tabular}

$*, * *$ and $* * *$ denote significance at the 10,5 and 1 percent level, respectively 